\title{
Surface Water Pollution Risk From Vietnam Water Quality Index (VN-WQI) in the Ca Mau City, Mekong Delta
}

\author{
Nguyen Ngan Ha*, Tran Thi Thu Huong*, Pham The Vinh*† and Tran Thi Van**(***) \\ *Southern Institute of Water Resources Research (SIWRR), Ho Chi Minh City, 70000, Vietnam \\ **Faculty of Environment and Natural Resources, Ho Chi Minh City University of Technology (HCMUT), \\ 268 Ly Thuong Kiet Street, District 10, Ho Chi Minh City, Vietnam \\ ***Vietnam National University Ho Chi Minh City, Linh Trung Ward, Thu Duc District, Ho Chi Minh City, Vietnam \\ †Corresponding author: Pham The Vinh; vinhsiwrr@gmail.com
}

Nat. Env. \& Poll. Tech.

Website: www.neptjournal.com

Received: 10-11-2020

Revised: 15-01-2021

Accepted: 22-01-2021

Key Words:

Multiple linear regression

Satellite image

VN-WQI

Water quality

Ca Mau city

\begin{abstract}
This paper presents the study of integrating the remote sensing technology with in-situ ground observation for assessing the status of water quality in Ca Mau city through the Vietnam Water Quality Index (VN-WQI). The Sentinel-2 image and in-situ surface water samples were collected on 20 February 2020 for this study. The sample results were then specified by samples' coordination. Besides, Sentinel-2 imaging was processed by radiometric and atmospheric correction, geometric registration, and extracted pixel spectral values from the sample locations. The multiple linear regressions of seven water quality parameters including $\mathrm{BOD}_{5}, \mathrm{COD}, \mathrm{NH}_{4}, \mathrm{PO}_{4}, \mathrm{TSS}, \mathrm{pH}$, Coliform with surface water's pixel spectral values from the satellite images were calculated and used to simulate water quality parameters on the satellite image. They were integrated into the VN-WQI to estimate, classify, and evaluate the general surface water quality of the $\mathrm{Ca}$ Mau city. The results show that there is a regressive correlation between measured data and image spectral values, and the simulation also well fits with the data with an acceptable error. The surface water quality of Ca Mau city is heavily polluted with almost all water quality parameters recognized at B1 to above B2 level according to the QCVN08-MT:2015/BTNMT. In terms of VN-WQI, the results also illustrate the low quality of surface water and heavy pollution only used for water transportation, not for domestic use. This approach can be a powerful method in spatially monitoring water quality and supporting environment management.
\end{abstract}

\section{INTRODUCTION}

Water is a critical factor that determines the success of strategies, planning, socio-economic development, ensures national security, water security, etc. but not like petroleum that can be replaced by other fuels such as electricity, biofuel, gas, etc. Water, although renewable, is a finite and irreplaceable resource. Many studies, actions, solutions, strategies, and more activities have been put in place and implemented to protect the Earth's water resources. In the field of water quality assessment, the remote sensing method is considered one of the optimal technology solutions for estimating water quality (Gholizadeh et al. 2016).

Citizens of Ca Mau city have been suffering from extremely polluted surface water as a result of river water containing high levels of organic compounds, nutrients, suspended particles, and microorganisms. In the face of this alarming situation, it is necessary to put in efforts and a lot of actions to overcome these environmental disasters and improve water quality. Assessing the water quality is one of the first actions taken into consideration. At present, the city still uses the traditional method of in-situ measurement with laboratory analysis. However, the number of water samples is not enough and cannot fully cover the surface water network of the city due to lack of human resources, budget, and the time required to conduct a field study. Moreover, this method is accurate at the point scale but does not give either the spatial or temporal view of water quality needed for accurate assessment or management of water bodies (Ritchie et al. 2003). Therefore, remote sensing technology is one of the best solutions to improve the cons of the in-situ measurement method by extracting spatial-temporal information on water quality with a high spatial resolution (Lim \& Choi 2015).

The assessment of water quality by applying remote sensing technology has been recognized in numerous studies and research projects. Many of those consider the correlation between water quality parameters and pixel values of satellite images. Alparslan et al. (2007) assessed the water quality at Ömerli Dam, Turkey by using the Landsat 7-ETM satellite data and measured water quality parameters (chlorophyll-a, 
suspended solid matter, Secchi disk, and total phosphate). The study showed that Landsat TM satellite data and water quality parameters at various locations of Ömerli Dam can be related through a regression analysis to constitute a model, which can be used to measure water quality parameters over the entire lake surface (Alparslan et al. 2007). Abdullah (2010) estimated multiple water indices by developing water quality models based on Landsat 8 image and four mathematical methods (NSFWQI, CCMEWQI, OWQI, and AWWQI) for twenty stations in Dokan Lake, Iraq. The thesis concluded that the AWWQI model gives the best results with the coefficient $\mathrm{R}^{2}$. Therefore, the relationship between the image bands of the Landsat OLI image and the water indicators is consistent (Abdullah 2010). In 2014, Waxter's study conducted a linear regression between Landsat 5 and in situ measurement of Hazardous Algae Blooms in North and South Tenmile Lakes in coastal Oregon, United States. Results show a good linear correlation between turbidity and radiance, which are inversely related in algal-dominated lakes (Waxter 2014). Another similar study is from Kapalanga (2015). The study had used Landsat 8 images to estimate multiple water parameters for the Olushandja dam in North-central Namibia. The author then concluded that the developed regression algorithms are best fit to predict water quality parameters from satellite data. Remote sensing is therefore recommended for frequent and continuous monitoring of Olushandja Dam as it has the ability to provide information about surface water quality (Kapalanga 2015). El-Zeny and El-Kafrawy (2016) also applied the regression model between calibrated Landsat 8 image and water parameters on Burullus Lake (El-zeny \& El-Kafrawy 2016). In 2017, Gholizadeh \& Melesse (2017) developed a multiple linear regression model for Florida Bay between the optical bands in the region from blue to near-infrared and all the possible band ratios to explore the relationship between the reflectance of the waterbody and observed data. They used Landsat 5 for data in the wet season and Landsat 8 for data in the dry season. The model gave high coefficients and is good to monitor and predict the spatiotemporal variations of the studied water quality parameters in Florida Bay (Gholizadeh $\&$ Melesse 2017). With the small scale of the study area as the Bin El reservoir, Karaoui et al. (2019) applied Sentinel-2 images to simulate the surface water indices (chlorophyll-a, dissolved oxygen, nitrates). The in-situ sampling was carried out in the Bin El Ouidane Reservoir (Azilal Province), followed by the analysis of physicochemical parameters in the laboratory. These measurement results were compared with the reflectance in each sampling location to investigate the correlations between bands and laboratory chemical analysis results. The correlation results showed that they can be transformed to predictive models by stepwise regression (Karaoui et al. 2019). In Vietnam, Dinh (2018) applied VNREDSAR-1A data (Vietnam's satellite images) to monitor the surface water of the Hanoi region. The study has built up the optimal model for calculating the four water indicators for two areas of the lagoon and the Red River. The research results had demonstrated the effectiveness and reliability of remote sensing technology in assessing and monitoring surface quality compared with traditional research methods (Dinh 2018). In 2019, Vo et al. (2019) Published a study on the applicability of Landsat imagery to estimate suspended sediment concentrations (SSC) on Tien and Hau rivers, Mekong Delta. The research results had identified a linear regression model with variables such as reflectance coefficients from the green and red channels capable of applying SSC estimation for the study area. The results showed that there is a strong correlation between the actual measured SSC data series and the estimated SSC according to the equation. Therefore, it is possible to study the changes of SSC on the river in the direction of the satellite image approach (Vo et al. 2019).

Based on the correlation between the water parameters and satellite image's pixel values, this paper applies the remote sensing technology for estimating seven water parameters include biochemical oxygen demand $\left(\mathrm{BOD}_{5}\right)$, chemical oxygen demand (COD), ammonium $\left(\mathrm{NH}_{4}\right)$, phosphate $\left(\mathrm{PO}_{4}\right)$, total suspended solids (TSS), $\mathrm{pH}$ and coliforms. The regression model was constructed between the in-situ measurements sampling points and four bands (blue, green, red, near-infrared) of the Sentinel-2 image. Both in-situ data and Sentinel-2 were collected on 20 February 2020. Furthermore, the VN-WQI was used in combination with Decision 1460/QD-TCMT to present and map the overall state of surface water quality in Ca Mau.

\section{MATERIALS AND METHODS}

\section{Study Area}

$\mathrm{Ca}$ Mau city, located in the east of Ca Mau province, is one of the driving forces of the Mekong Delta's core economic zone (Fig. 1).

There are four types of land use in Ca Mau city which include residential areas, shrimp ponds, aquaculture areas, and perennial crop farms. Aquaculture land accounts for $57.1 \%$ of the city's total area. Residential areas and shrimp ponds are in second and third place, with $25.2 \%$ and $11.9 \%$, respectively. Perennial cropland makes up only $0.4 \%$ of the total land area. The rest of the city has a water layer of $5.3 \%$.

\section{Datasets}

\section{Satellite Image}

The satellite image used in this study is the Sentinel-2 MSI 
level 2A (S2A) acquired on 20 February 2020 collected from the European Space Agency (ESA). The Level-2A product provides Bottom of Atmosphere (BOA) reflectance images derived from the associated Level-1C products. Each Level-2A product is composed of $100 \times 100 \mathrm{~km}^{2}$ tiles in cartographic geometry (UTM/WGS84 projection) (ESA, 2020). There are 13 bands in the Sentinel 2 image. According to the principle of spectral reflection on the electromagnetic spectrum, water objects have strong reflectivity in short wavelengths. Besides that, from many previous studies about the relationship between surface water quality and satellite pixel values, this study utilized $10 \mathrm{mx} 10 \mathrm{~m}$ of resolution image with its four bands blue (band 2), green (band 3), red (band 4), and near-infrared (band 8) to determine the multiple linear regression between the field data and the satellite reflectance values (Engman \& Gurney 1991, Seyhan \& Dekker 1986, Zhu et al. 2011, Fiorani et al. 2006, Imen et al. 2014, Chang et al. 2014).

\section{Field Data}

We conduct field sampling in the dry season to reduce the cloud or rain effects from the weather conditions, and to consist of the Sentinel 2A image captured time samples collected from 10:00 to 10:45 am on 20 February 2020. We divided into three teams to collect 51 samples from major rivers, canals, and lakes in the study area. Fig. 2 shows the sampling routes and 51 sample locations.

\section{Spatial Data}

Instead of satellite images and field samples, spatial data such as administrative boundaries, existing land use, canals, and street networks can be used for satellite geo-processing, extracting the study area, developing the water quality zoning maps, and analyzing the results.

\section{Mathematical Approach}

There are five main stages in this study which include (1) Collecting and assessing in-situ data following the National technical regulation of surface water quality QCVN08-MT:2015/BTNMT; (2) Pre-processing the Sentinel 2A image; (3) Specifying pixel spectral values with the measured data; (4) Calculating and applying the multiple linear regression on the satellite image; (5) Applying VN-WQI from Decision 1460/QD-TCMT and establishing the classification map of surface water quality (VN-WQI map) (Fig. 3).

\section{Preprocessing of Satellite Image}

The image preprocessing stage was implemented in three

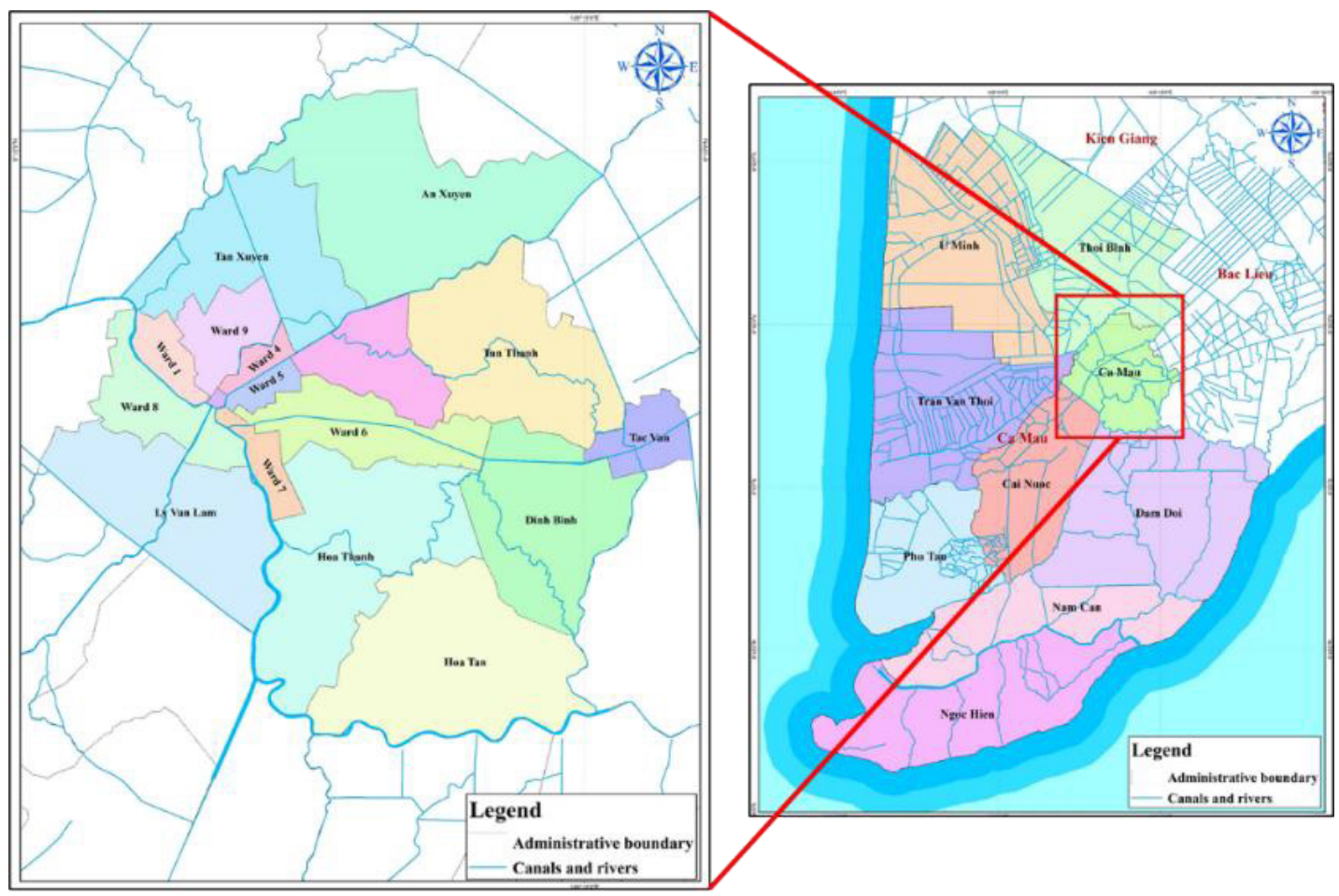

Fig. 1: Ca Mau city location. 


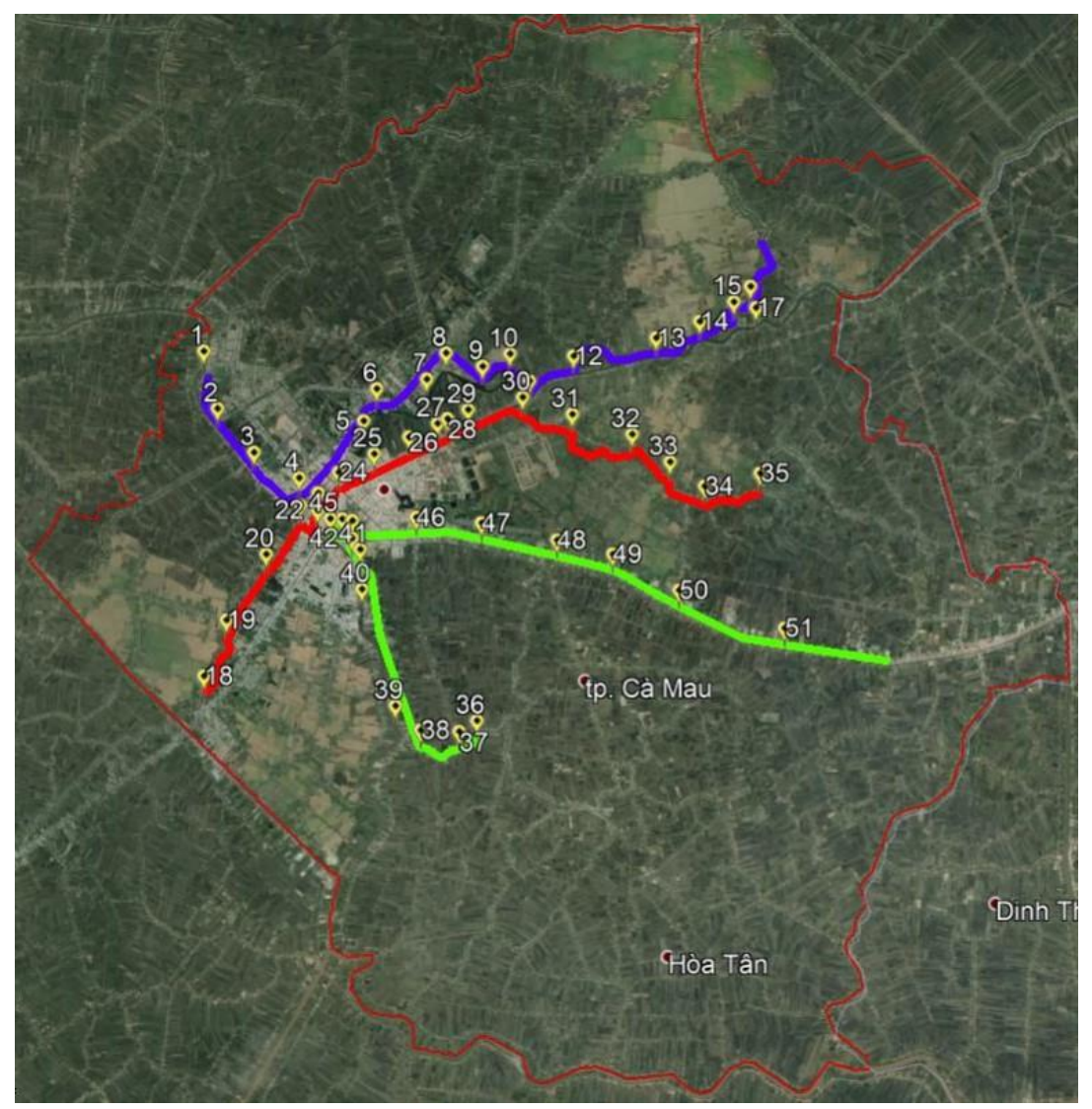

Fig. 2: The study sites with sampling routes and sample locations.

steps include (1) spatial resampling, (2) radiometric calibration, and (3) geoprocessing.

The S2A product requires spatial resampling since the bands are measured at different spatial resolutions. Due to the size of the study area, a resolution of $10 \mathrm{~m}$ is required to retrieve the best pixel values. The resampling used band 2 with $10 \mathrm{~m}$ to up-sampling with a larger spatial resolution (20m and $60 \mathrm{~m}$ ) onto a grid with a higher spatial resolution. This step is done by the Nearest neighbor sampling method whereas every pixel value in the output product is set to the nearest input pixel value. Each output cell value in the nearest neighbor method is the unmodified value from the closest input cell (ESA 2019).

The next step is the radiometric calibration to convert the surface reflectance into the radiance values as the S2A has already been calibrated from the raw DN (Digital Numbers) into the surface reflectance by using solar irradiance in each wavelength at the time of acquisition. In this study, the FLASH method was applied to four bands of resampled $\mathrm{S} 2 \mathrm{~A}$ products mentioned above. This computation has the general form:

$$
\mathrm{L}_{\lambda}=\text { gain } * \text { cell value }+ \text { offset }
$$

Where $\mathrm{L}_{\lambda}$ is the radiance [Watts $/\left(\mathrm{m}^{2} * \operatorname{steradian} * \mu \mathrm{m}\right)$ ]

The last step is geoprocessing the calibrated S2A to reduce the error that comes from satellite shooting angles. This study used the Ground Control Point (GCP) method for the image geo-reference. Five control points were selected for the geo-reference. The Root Mean Square Error (RMSE) showed 0.26 which is below 0.5 as the required rule.

\section{Surface Water Layer Extraction}

The iso cluster unsupervised classification method was utilized for the surface water extraction. The iso cluster algorithm is an iterative process for computing the minimum Euclidean distance when assigning each candidate cell to a cluster (ESRI 2020a). Generally, the more cells contained in the extent of the intersection of the input bands, the larger the values for minimum class size and sample interval should be specified (ESRI 2020b).

$$
Z=\frac{(X-\text { oldmin }) \times(\text { newmax }- \text { newmin })}{(\text { oldmax }- \text { oldmin })}+\text { newmin }
$$




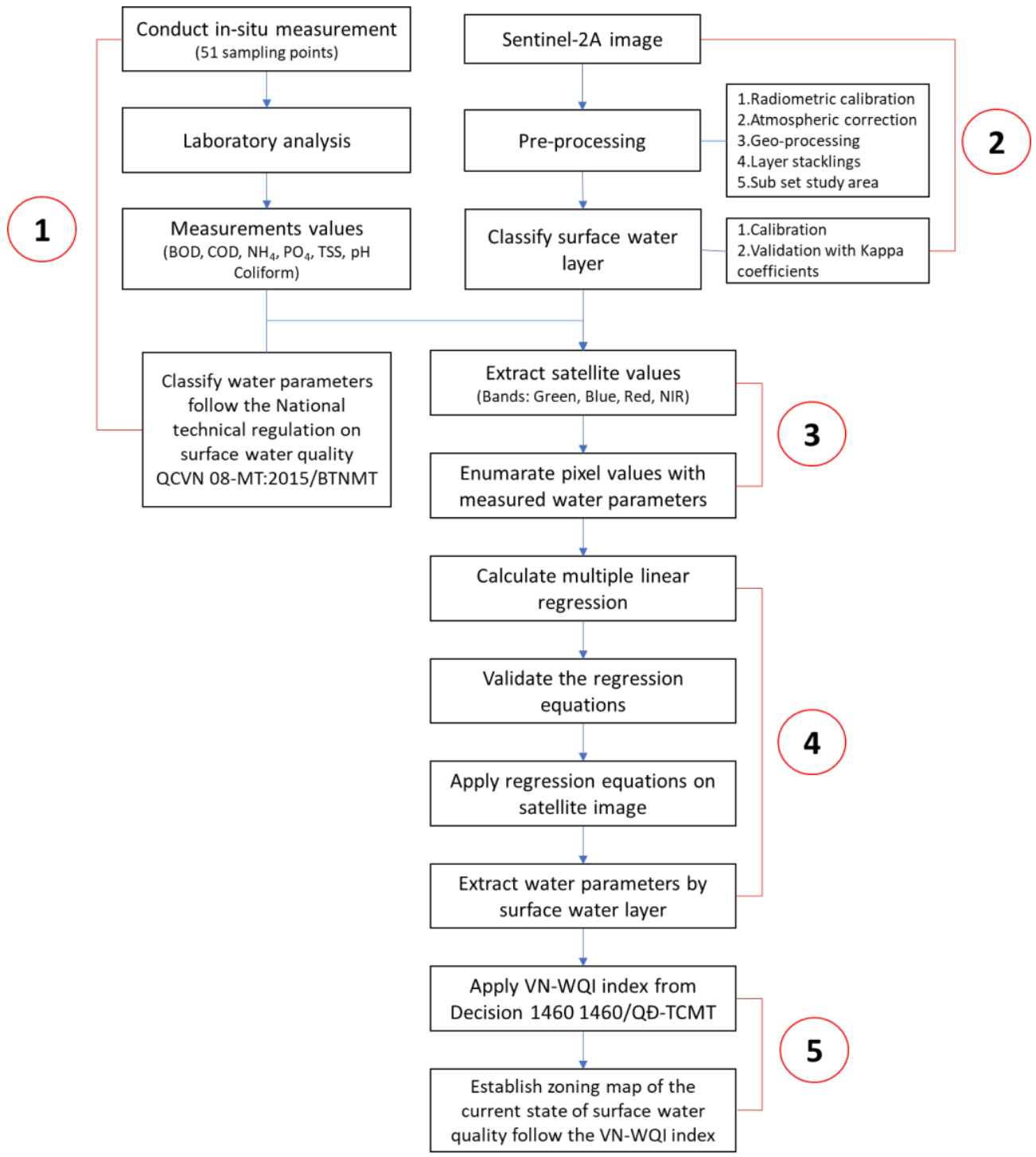

Fig. 3: Different steps for the WQI mapping process.

Where $\mathrm{Z}$ is the output raster with new data ranges; $\mathrm{X}$ is the input raster; oldmin is the minimum value of the input raster; oldmax is the maximum value of the input raster; newmin is the desired minimum value for the output raster; newmax is the desired maximum value for the output raster.

\section{Multiple Linear Regression Calculation}

The multiple linear regression between measured parameters $\left(\mathrm{BOD}_{5}, \mathrm{COD}, \mathrm{NH}_{4}, \mathrm{PO}_{4}, \mathrm{TSS}, \mathrm{pH}\right.$, and Coliform) and the satellite pixel values (bands $2,3,4,8$ ) of 38 out of 51 sample locations was conducted. The regression function is expressed in detail in equation 3 . $y_{i}=\mathrm{a}+\mathrm{b} x_{i, B 2}+c x_{i, B 3}+d x_{i, B 4}+e x_{i, B 8}$

Where $\mathrm{i}$ is a study site; yi is the measured parameter of the study site $\mathrm{i}$; (dependent variable); $\mathrm{xi}$ is the pixel values of the study site $\mathrm{i}$ in bands blue, green, red, or NIR (independent variable). B2, B3, B4, B8 are bands blue, green, red, and NIR respectively.

These regression equations then are validated by five statistical indices in Excel software: $\mathrm{R}$ square $\left(\mathrm{R}^{2}\right)$, adjusted $\mathrm{R}$ square (Adj. $\mathrm{R}^{2}$ ), $t$-Stat, $p$-value, and Significance- $F$ (Sig. F).

After applying the validated regression equation on the S2A, three parameters include Bias, RMSE, and Percentage 
of Error (PE) were calculated to validate the simulated results with the measured values. These parameters are defined as equations $4,5,6$.

Bias $=$ Bias $=\frac{1}{n} \sum_{i=1}^{n}\left(X_{i}-Y_{i}\right)$

$\operatorname{RMSE}=\sqrt{\frac{1}{n} \sum_{i=1}^{n}\left(X_{i}-Y_{i}\right)^{2}}$

$\mathrm{PE}=\frac{1}{n} \sum_{i=1}^{n}\left|\frac{X_{i}-Y_{i}}{X_{i}}\right| \times 100$

Where $\mathrm{X}_{\mathrm{i}}, \mathrm{Y}_{\mathrm{i}}$ are estimated values and ground data values, respectively, $\mathrm{n}$ is the number of samples.

The regressions equations accepted as the above parameters meet the following criteria: $\mathrm{R}^{2} \geq 0.8$, adj. $\mathrm{R}^{2} \geq 0.8, t$-Stat $\geq|2|, p$-value $\leq 0.05$, and Sig. $F \leq 0.05$

\section{VN-WQI Calculation}

From the multiple water quality parameters, the integrated index to provide the general assessment of water quality is required. The VN-WQI is utilized to classify the water quality of the study area. This index was calculated based on the Decision 1460/QD-TCMT regarding the promulgation of Technical Guidelines for calculation and publication of the Vietnam Water Quality Index (VN-WQI). VN-WQI was calculated from five groups of parameters including (Group I) $\mathrm{pH}$ index; (Group II) Crop protection agent; (Group III)
Heavy metal parameters; (Group IV) Organic and Nutrient parameters; and (Group V) microorganism parameters.

To calculate the WQI, it is necessary to select at least three out of five specified groups (from Group I to Group V), of which three parameters from Group IV are required. Therefore, this paper chooses to calculate seven criteria: $\mathrm{BOD}_{5}, \mathrm{COD}, \mathrm{NH}_{4}^{+}, \mathrm{P}_{-} \mathrm{PO}_{4}{ }^{3}$, TSS (Group IV), Coliform (group V), and $\mathrm{pH}$ (Group I). The summary formula of VNWQI is shown as equation 7.

$W Q I=\frac{W Q I_{I}}{100} \times \frac{\left(\prod_{i=1}^{n} \mathrm{w} Q I_{I I}\right)^{1 / n}}{100} \times \frac{\left(\prod_{i=1}^{m} \mathrm{w} Q I_{I I I}\right)^{1 / \mathrm{m}}}{100} \times\left[\frac{1}{k} \sum_{i=1}^{k} W Q I_{I V} \times \frac{1}{l} \sum_{i=1}^{l} W Q I_{V}\right]^{1 / 2}$

Where $\mathrm{WQI}_{\mathrm{I}} / \mathrm{WQI}_{\mathrm{II}} / \mathrm{WQI}_{\mathrm{III}} / \mathrm{WQI}_{\mathrm{IV}} / \mathrm{WQI}_{\mathrm{V}}$ are the results of WQI by groups I to V, respectively. These WQIs are calculated and classified following the Decision 1460/ QD-TCMT (Table 1).

\section{RESULTS AND DISCUSSIONS}

\section{Ground Measured Water Quality Parameter Assessment by Sampling Locations}

The National technical regulation on surface water quality, QCVN 08-MT:2015/BTNMT, governs four groups for the classification of surface water sources for the purposes of assessing and controlling water quality for various purposes. These four values are described in Table 2 . The limit values for each water parameter are shown in Table 3 .

Table 1: Surface water quality classified by VN-WQI.

\begin{tabular}{|llll|}
\hline & & VN-WQI index \\
\hline WQI value range & Water quality & Color & Utilization purpose \\
\hline $90-100$ & Very good & Food for domestic water supply purposes \\
$75-90$ & Good & For domestic water supply purposes but need appropriate treatment measures \\
$50-75$ & Average & For water transportation and other similar purposes \\
$25-50$ & Very poor & & Teavily polluted water, needing treatment measures in the future \\
$10-25$ & Heavily polluted & &
\end{tabular}

Table 2: Classification of surface water quality by QCVN 08-MT:2015/BTNMT.

\begin{tabular}{|ll|}
\hline Group & Description \\
\hline A1 & Good use for domestic water supply and other purposes, such as A2, B1, and B2 \\
A2 & $\begin{array}{l}\text { For domestic water supply, but must apply the appropriate treatment technology, conservation of aquatic animals and plants, or other } \\
\text { purposes, such as B1 and B2 }\end{array}$ \\
B1 & For irrigation purposes or other purposes requiring similar quality standards or for the purposes as B2 \\
B2 & Water transport and other purposes with low-quality water requirements \\
\hline
\end{tabular}


From the classification standard (Table 2), Fig. 4 illustrates the surface water quality of 51 samples taken in the study area on 20 February 2020. Water characteristics obtained from Ca Mau's principal rivers, canals, and lakes, as shown in Table 3, generally indicate poor surface water quality, with the majority of the results falling between B1 and $\mathrm{B} 2$. In detail, except for the $\mathrm{pH}$ value is in group $\mathrm{A} 1$ all the other parameters have values from $\mathrm{B} 1$ to $\mathrm{B} 2$ level and even exceed the B2 level. Especially TSS and $\mathrm{PO}_{4}$, most of the values are above B2. This data indicates that the state of surface water quality is severely polluted, indicating that the local government must take suitable actions and implement solutions to enhance water quality.

\section{Multiple Linear Regression Results}

The regression was conducted from the statistic of in-situ surface water quality parameters with pixel spectral values of four bands (blue, green, red, and NIR) at 38 sample locations as mentioned before. However, in our first calculation, we observed that each parameter correlated with different bands combinations according to the $t$-Stat and the $p$-value. In general, the $t$-stat $\geq|2|$ and $p$-value $\leq 0.05$ show that the parameter and satellite band have a good relationship. Otherwise, they have a weak correlation.

The first calculation result is presented in Table 4. From this table, $\mathrm{NH}_{4}$ and $\mathrm{pH}$ have a good relationship with all four bands. The $\mathrm{BOD}_{5}$ and $\mathrm{COD}$ do not correlate with the NIR band with $t$-stat below 12 . The same situation with $\mathrm{PO}_{4}$ and Coliform parameters. Last, the TSS parameter only correlates with bands green and red. Therefore, we removed bands that do not have a good relationship with water parameters, and then recalculated and derived new regression equations (Table 5).

Table 3: Limit values of surface water quality QCVN 08-MT:2015/BTNMT.

\begin{tabular}{|lllllll|}
\hline No. & Parameter & Unit & \multicolumn{3}{c|}{ Limit values } \\
\cline { 4 - 6 } & & $\mathrm{A} 1$ & $\mathrm{~A} 2$ & $\mathrm{~B} 1$ & $\mathrm{~B} 2$ \\
\hline 1 & $\mathrm{BOD}_{5}\left(20^{\circ} \mathrm{C}\right)$ & $\mathrm{mg} / \mathrm{L}$ & 4 & 6 & 15 & 25 \\
2 & $\mathrm{COD}$ & $\mathrm{mg} / \mathrm{L}$ & 10 & 15 & 30 & 50 \\
3 & $\mathrm{NH}_{4}{ }^{-}$ & $\mathrm{mg} / \mathrm{L}$ & 0.3 & 0.3 & 0.9 & 0.9 \\
4 & $\mathrm{PO}_{4}{ }^{-}$ & $\mathrm{mg} / \mathrm{L}$ & 0.1 & 0.2 & 0.3 & 0.5 \\
5 & $\mathrm{TSS}$ & $\mathrm{mg} / \mathrm{L}$ & 20 & 30 & 50 & 100 \\
6 & $\mathrm{pH}$ & - & $6-8.5$ & $6-8.5$ & $5.5-9$ & $5.5-9$ \\
7 & Coliform & MPN/100 $\mathrm{ml}$ & 2,500 & 5,000 & 7,500 & 10,000 \\
\hline
\end{tabular}

Table 4: Statistic of $t$-Stat and $p$-value from regression analysis.

\begin{tabular}{|c|c|c|c|c|c|}
\hline Water quality parameter & Parameter/Band & BLUE & GREEN & RED & NIR \\
\hline \multirow[t]{2}{*}{$\mathrm{BOD}_{5}$} & $t$ Stat & 39.245 & -44.410 & 17.608 & 0.865 \\
\hline & P-value & 0.000 & 0.000 & 0.000 & 0.000 \\
\hline \multirow[t]{2}{*}{ COD } & $t$ Stat & 14.811 & -16.889 & 7.072 & 0.701 \\
\hline & $P$-value & 0.000 & 0.000 & 0.000 & 0.000 \\
\hline \multirow[t]{2}{*}{$\mathrm{NH}_{4}$} & $t$ Stat & 9.152 & 6.598 & -20.754 & 51.535 \\
\hline & $P$-value & 0.000 & 0.000 & 0.000 & 0.000 \\
\hline \multirow[t]{2}{*}{$\mathrm{PO}_{4}$} & $t$ Stat & 36.151 & -40.856 & 13.297 & 0.674 \\
\hline & $P$-value & 0.000 & 0.000 & 0.000 & 0.000 \\
\hline \multirow[t]{2}{*}{ TSS } & $t$ Stat & -1.089 & -38.498 & 61.365 & 1.215 \\
\hline & $P$-value & 0.000 & 0.000 & 0.000 & 0.000 \\
\hline \multirow[t]{2}{*}{$\mathrm{pH}$} & t Stat & 2.237 & -17.509 & 15.312 & 22.692 \\
\hline & $P$-value & 0.000 & 0.000 & 0.000 & 0.000 \\
\hline \multirow[t]{2}{*}{ Coliform } & $t$ Stat & -178.232 & 157.395 & 82.680 & -0.036 \\
\hline & $P$-value & 0.000 & 0.000 & 0.000 & 0.000 \\
\hline
\end{tabular}



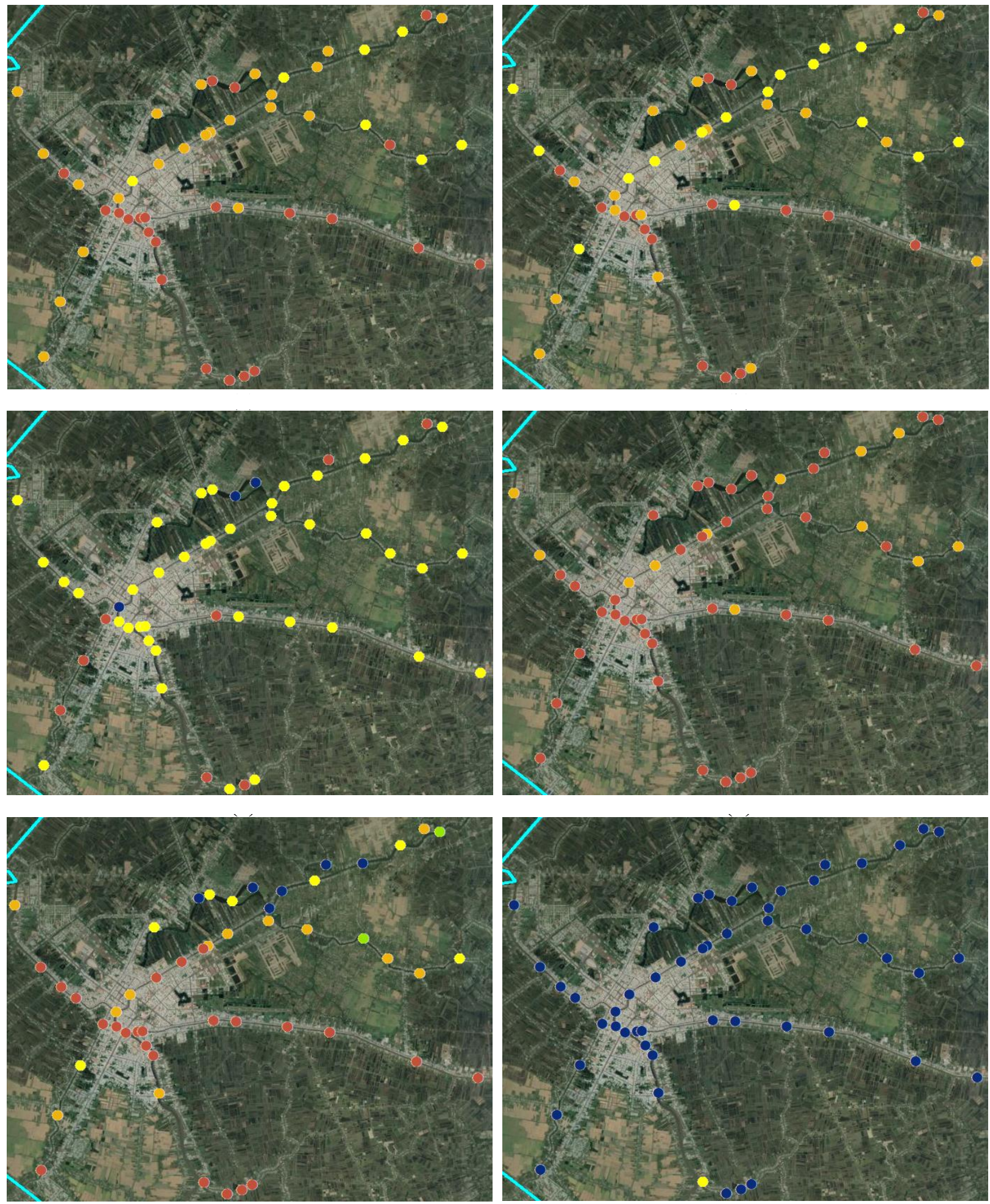

Fig. 4 Cont.... 


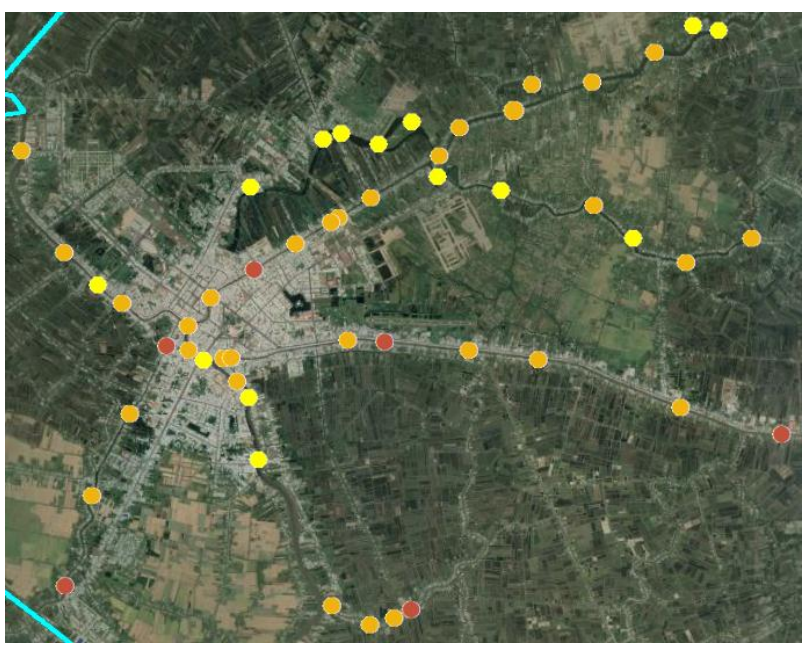

\begin{tabular}{l|l|l|l|l|}
$\mathrm{A} 1$ & $\mathrm{~A} 2$ & $\mathrm{~B} 1$ & $\mathrm{~B} 2$ & $>\mathrm{B} 2$ \\
\hline
\end{tabular}

Fig. 4: Classification of measured surface water quality by QCVN 08-MT:2015/BTNMT:

(a) $\mathrm{BOD}_{5}$, (b) $\mathrm{COD}$, (c) $\mathrm{NH}_{4}$, (d) $\mathrm{PO}_{4}$, (e) TSS, (f) $\mathrm{pH}$, and (g)Coliform

From Table 5, the regressions equations of all water quality parameters show its $\mathrm{R}^{2}$ and adjusted $\mathrm{R}^{2}$ above 0.9 , and significance $\mathrm{F}$ below 0.05 . Therefore, the measured parameters and satellite bands have a significant regressive correlation. Thus, water quality parameters can be achieved by applying these regression equations on the
S2A. 13 remaining measured data was used to evaluate the simulation results by applying the derived regression equations and the statistical parameters include bias, percentage error (PE), and RMSE. Table 6 presents the simulation results of 13 remaining measured data and its validation.

Table 5: Recalculated multiple linear regression equations.

\begin{tabular}{|c|c|c|c|c|}
\hline Water quality parameter & Regression equation derived & $\mathrm{R}^{2}$ & Adj. $R^{2}$ & Sig. F \\
\hline $\mathrm{BOD}_{5}$ & $25.57+14167.79 \times$ B $-16071.25 \times$ G $+5222.30 \times R$ & 0.988 & 0.987 & 0.000 \\
\hline COD & $40.70+22453.20 \times B-25817.64 \times G+9021.55 \times R$ & 0.930 & 0.923 & 0.000 \\
\hline $\mathrm{NH}_{4}$ & $-0.009+108.99 \times \mathrm{B}+78.35 \times \mathrm{x}-198.09 \times \mathrm{R}+189.53 \times \mathrm{N}$ & 0.992 & 0.991 & 0.000 \\
\hline $\mathrm{PO}_{4}$ & $1.094+590.20 \times$ B $-665.99 \times \mathrm{G}+178.03 \times \mathrm{R}$ & 0.986 & 0.984 & 0.000 \\
\hline TSS & $44.20-55467.75 \times \mathrm{G}+69783.92 \times \mathrm{R}$ & 0.998 & 0.998 & 0.000 \\
\hline $\mathrm{pH}$ & $7.20+56.033 \times \mathrm{B}-437.31 \times \mathrm{G}+307.42 \times \mathrm{R}+175.540 \times \mathrm{N}$ & 0.985 & 0.983 & 0.000 \\
\hline Coliform & $6076.83-2025482.56 \times \mathrm{B}+1783177.80 \times \mathrm{G}+290083.64 \times \mathrm{N}$ & 0.970 & 0.970 & 0.000 \\
\hline
\end{tabular}

( $\mathrm{B}$ is band blue, $\mathrm{G}$ is band Green, $\mathrm{R}$ is band red and $\mathrm{N}$ is band near-infrared)

Table 6: The area percentage of the simulation results classified by QCVN 08-MT:2015/BTNMT.

\begin{tabular}{|c|c|c|c|c|c|}
\hline Parameter/Level & $\mathrm{A} 1$ & $\mathrm{~A} 2$ & B1 & B2 & $>\mathrm{B} 2$ \\
\hline BOD & 4.82 & 3.31 & 22.80 & 43.78 & 25.29 \\
\hline COD & 7.03 & 5.16 & 28.23 & 49.95 & 9.63 \\
\hline $\mathrm{NH}_{4}$ & 2.87 & & 46.59 & & 50.54 \\
\hline $\mathrm{PO}_{4}$ & 4.82 & 7.07 & 7.69 & 17.59 & 62.83 \\
\hline TSS & 2.18 & 1.83 & 6.36 & 37.43 & 52.21 \\
\hline $\mathrm{pH}$ & 0.003 & 0.03 & 5.13 & 45.05 & 49.79 \\
\hline Coliform & 99.30 & & 0.69 & & - \\
\hline
\end{tabular}


The simulation results from the 13 remaining samples are very close to the in-situ measurements (Fig. 5). The bias of seven parameters are all less than 3 with $0.31\left(\mathrm{BOD}_{5}\right)$, 0.13 (COD), $0.001\left(\mathrm{NH}_{4}\right), 0.006\left(\mathrm{PO}_{4}\right),-1.66$ (TSS), 0.009 $(\mathrm{pH})$, and -2.82 (Coliform). However, the estimated Coliform is still accepted and can illustrate a good simulation. The percentage error also witnessed good values with all values is under $5 \%$ with $1.51 \%\left(\mathrm{BOD}_{5}\right), 1.89 \%(\mathrm{COD})$,
4.02\% $\left(\mathrm{NH}_{4}\right), 0.006\left(\mathrm{PO}_{4}\right), 3.09 \%(\mathrm{TSS}), 0.95 \%(\mathrm{pH})$, and $0.60 \%$ (Coliform). The RMSE also presents the strong relationship between estimated and measured data with 0.66 $\left(\mathrm{BOD}_{5}\right), 1.25$ (COD), $0.03\left(\mathrm{NH}_{4}\right), 0.05\left(\mathrm{PO}_{4}\right),(2.14) \mathrm{TSS}$, $0.06(\mathrm{pH})$, and 24.7 (Coliform). Therefore, the simulation results achieved from the estimated regression equations and the S2A can indicate the real water quality data with reliable accuracy.
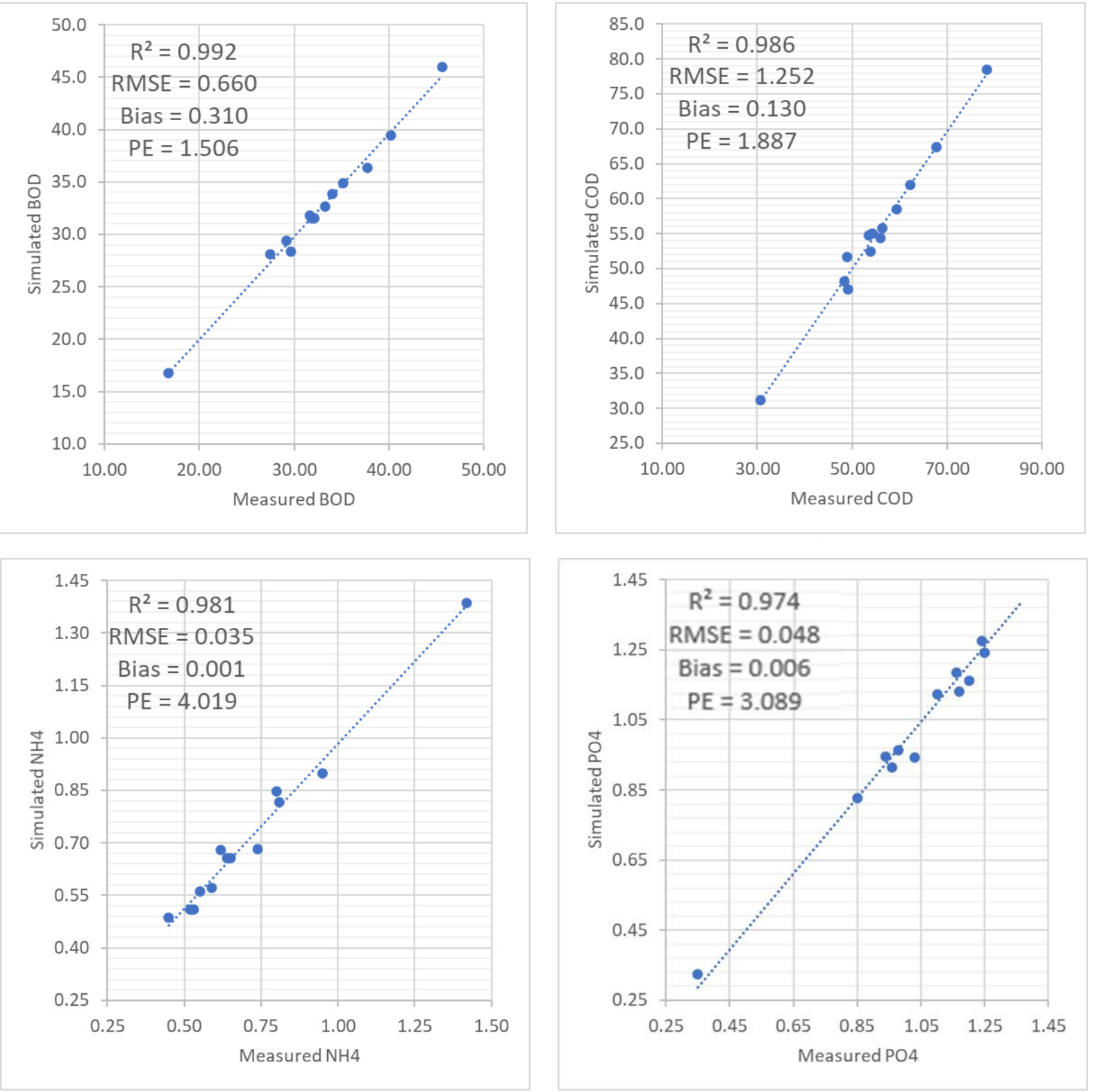


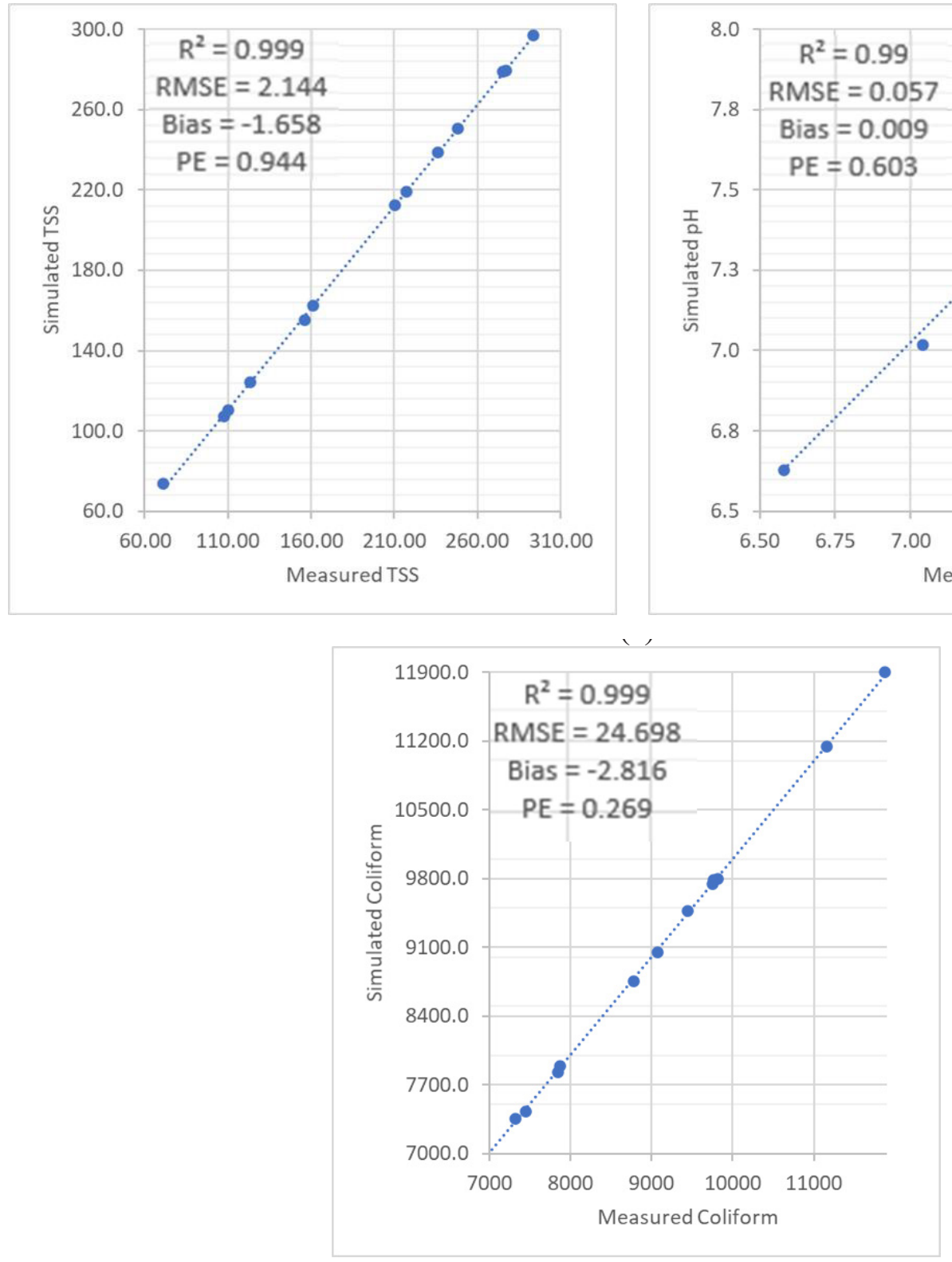

Fig. 5: Comparison of water quality parameters derived from Sentinel-2A and measured data on 20 February 2020: (a) $\mathrm{BOD}_{5}$, (b) $\mathrm{COD}$, (c) $\mathrm{NH}_{4}$, (d) $\mathrm{PO}_{4}$, (e) TSS, (f) $\mathrm{pH}$, and (g)Coliform

\section{Water Quality Parameters Derived from Sentinel-2A}

Table 6 is the area percentage of the simulated water quality parameters by concentration level classified by QCVN 08MT:2015/BTNMT.

With $\mathrm{BOD}_{5}$, level B2 (15-25 mg. $\left.\mathrm{L}^{-1}\right)$ covered the most of surface water area with $43.78 \%$ of the area. On the other hand, levels A1 (<4 mg. $\left.\mathrm{L}^{-1}\right)$ and A2 (4-6 mg/L) levels covered a small area with only $4.82 \%$ and $3.31 \%$. The same trend appears in COD when $49.95 \%$ of the study area was level B2 (30-50 mg.L ${ }^{-1}$ ). Levels A1 and A2 still came last with 7.03\% and $5.16 \%$ of the distribution area. In terms of $\mathrm{NH}_{4}, 50.54 \%$ of the Ca Mau city's surface water is distributed above the B2 level (>0.93 mg. $\left.\mathrm{L}^{-1}\right)$. In contrast, the A-level (A1 and A2) assigned only $2.87 \%$. In $\mathrm{PO}_{4}$ parameters, the concentration above $0.5 \mathrm{mg} . \mathrm{L}^{-1}$ (above B2 level) accounted for the highest 
proportion, at $62.83 \%$ of the total area. Meanwhile, the lowest figures can be seen in the percentage of A1 level $\left(<0.1 \mathrm{mg} . \mathrm{L}^{-1}\right)$, at nearly $4.8 \%$. TSS parameter has a similar trend with the $\mathrm{PO}_{4}$ when more than $100 \mathrm{mg} . \mathrm{L}^{-1}$ of TSS (above B2 level) covered most of the city's surface water area with $52.21 \%$ of the total area. Meanwhile, A1 and A2 levels have the lowest figures, at $2.18 \%$ and $1.83 \%$. In the Coliform parameter, the proportions of above B2 ( $>10,000$
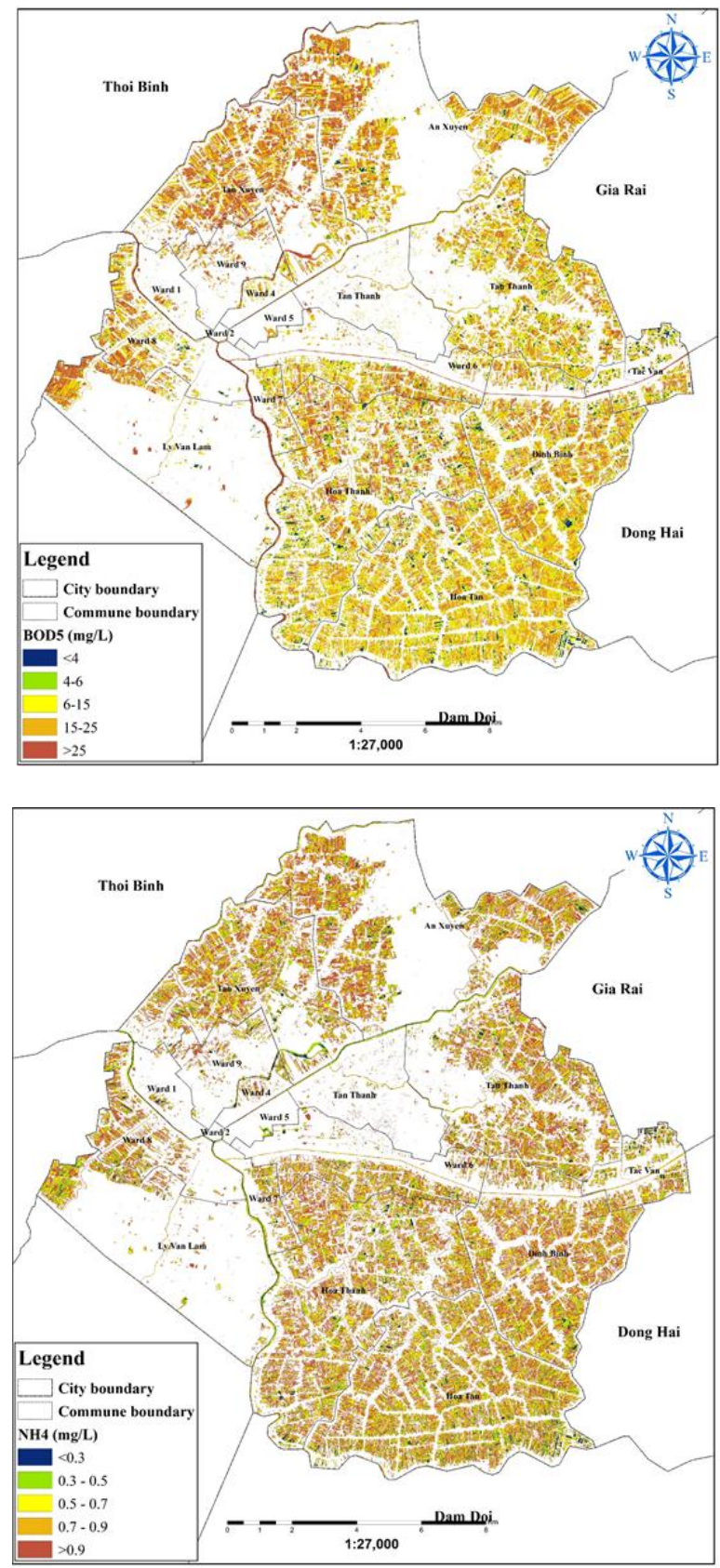

MPN/100mL) and B2 (7,500-10,000 MPN100mL) levels were high, at $49.79 \%$ and $45.05 \%$ while the level A1 allocated only about $0.003 \%$ respectively. In contrast to the above parameters, the A-level (A1 and A2) of $\mathrm{pH}$, which ranges from 6 to 8.5, is predominantly found in surface water, accounting for $99.30 \%$ of the total. Meanwhile, the B-level (B1 and B2) covered a very small area, about $0.69 \%$ of the area.
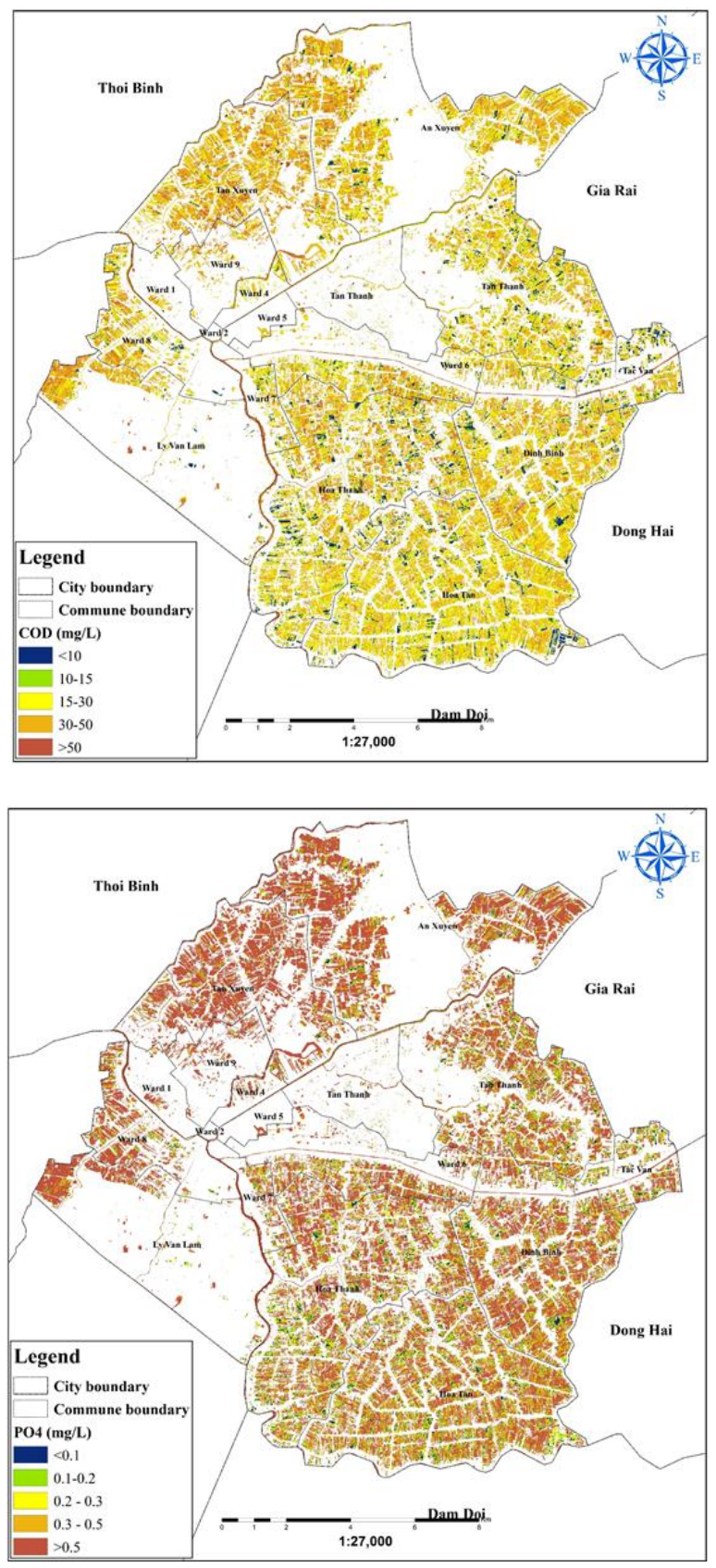

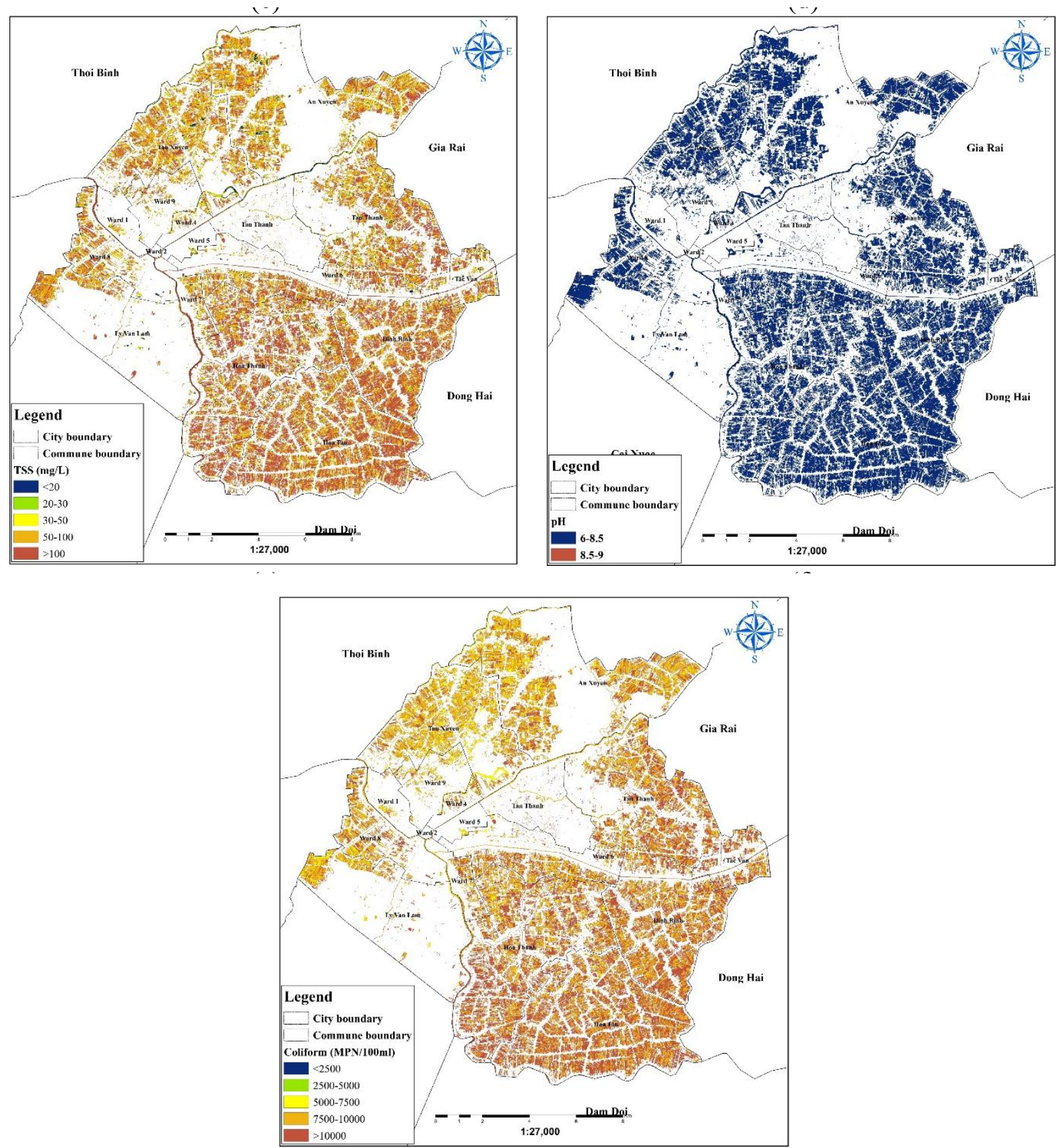

Fig. 6: Seven parameters with limit value ranges for water quality analysis by QCVN 08-MT:2015/BTNMT achieved from the S2A: (a) BOD 5 , (b) COD, (c) $\mathrm{NH}_{4}$, (d) $\mathrm{PO}_{4}$, (e) TSS, (f) pH, and (g)Coliform.

In general, except for $\mathrm{pH}$, all other parameters have a very high concentration (equivalent B1, B2, and above B2 levels) that appeared in most surface water in Ca Mau city. Meanwhile, the A-level (A1 and A2) comprises a small area in which water is used for drinking. With the current status of the seven water quality parameters at the image acquisi- tion time, the surface water of $\mathrm{Ca}$ Mau city seems heavily polluted. However, the concentration levels of each parameter have a fragmented distribution and cannot provide the overall assessment of the surface water quality. Therefore, the VN-WQI index was used to derive the general surface water quality from the above seven parameters. 


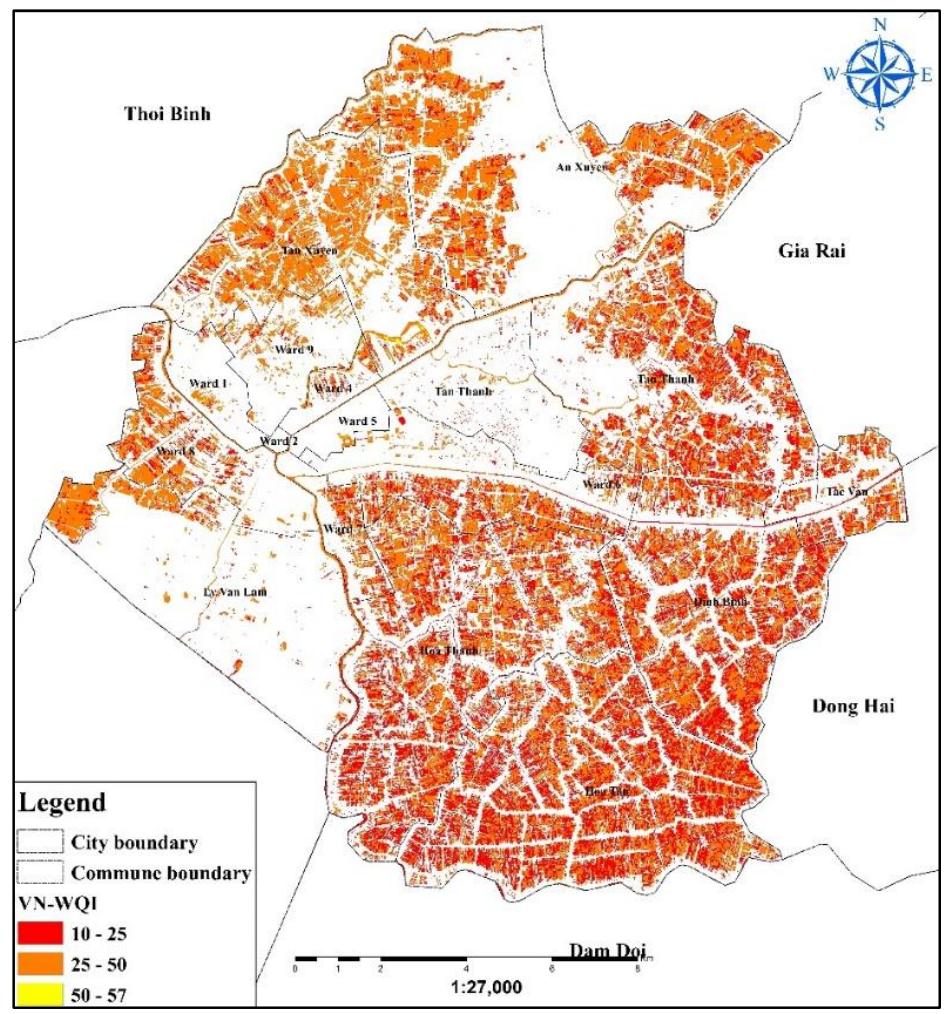

Fig. 7: General surface water quality classified by VN-WQI.

\section{General Surface Water Quality Classification by VN- WQI}

To have a general assessment for the surface water quality, the VN-WQI was conducted and its result was classified according to the Decision 1460/QD-TCMT approved by Vietnam Environment Administration (2019) mentioned in the above VN-WQI in the above section. The results are illustrated in Table 7 and Fig. 7. In general, statistical results showed that there are three WQI levels detected in the study area, 10-25, 25-50, and 50-75, and have an uneven distribution. WQI levels 10-25 and 25-50 are most detected in surface waters of Ca Mau city, with levels 10-25 occurring most in the south and the east while 25-50 mainly distributed in the northwest and the northeast of this city. As a result, the surface water quality in Ca Mau city is low, with a level of 10-25 indicating that the water is extremely polluted and will require treatment in the future, and a level of 25-50 indicating that the water is only utilized for water transportation and other similar reasons. On the other side, the surface water used for irrigation and other similar purposes contained a small proportion (level 50-75), and there was no surface water area that suitable for domestic water supply.

More specifically, level 50-75 has a low figure of $0.11 \%$ and is dispersed around the city. It's particularly common in the Tan Xuyen district. The WQI 10-25 level, on the other hand, accounts for around $41 \%$ of the entire surface water area in Ca Mau city, with most of it concentrated in the city's south and east. The area distribution on the side of levels 25-50 accounted for the highest percentage of the total area distribution at $58.7 \%$. Levels 25-50, like levels 10-25, are dispersed around the city. However, it concentrated in the northwest and northeastern areas. Both of these WQI levels mainly occur in aquaculture and industrial areas, residential area, and shrimp ponds in An Xuyen, Hoa Tan, Hoa Thanh, Ly Van Lam districts, and Tan Thanh commune.

Table 7: Distribution of VN-WQI result by classification level.

\begin{tabular}{|c|c|c|c|}
\hline VN-WQI classification level & $10-25$ & $25-50$ & $50-75$ \\
\hline Area (ha) & 3874.14 & 5529.06 & 10.56 \\
\hline Percentage of area $(\%)$ & 41.15 & 58.73 & 0.11 \\
\hline
\end{tabular}


One of the reasons to explain this situation is that the wastewater comes from industrial parks, specifically Hoa Trung Industrial park located in the south of the city. There are currently nine industrial production establishments (five seafood processing facilities and four processing facilities for chitin and fish sauce) that generate a lot of odors, exhaust gas, polluted wastewater. There is no centralized industrial wastewater treatment system. The majority of the manufacturing facilities are near the Luong The Tran canal, and many of the dumping locations are beneath riverbank dwellings, making it difficult to regulate the discharge. Also, due to the production characteristics of chitin and fish sauce, there is a lot of odor widely dispersed. Many facilities have not installed the odor collection and treatment system. Song Doc industrial cluster and the contiguous area have 12 industrial production establishments (three seafood processing facilities and nine fishmeal facilities) that generate a lot of smoke, odor, and wastewater from industrial production activities. Over more, the type of fishmeal production with the separated rice husk boiler technology generates a lot of dust and gas emissions into the surrounding environment. Many small businesses that produce chitin and perform basic processing on aquatic items do not have wastewater treatment facilities, therefore pollution levels are rising near the industrial park. The PC also determines that the residential areas concentrated in the inner $\mathrm{Ca}$ Mau and Song Doc town (Tran Van Thoi district) are regularly polluted due to indiscriminate waste in the vacant land, ponds. Up to now, this area has formed spontaneous landfills with large volumes (Huynh 2018). Moreover, in residential areas, domestic wastewater and leachate from spontaneous landfills are discharged directly into rivers and canals of this city, also causing serious surface water pollution.

\section{CONCLUSIONS}

The results showed that the measured data and the satellite image values have a significant linear relationship. The obtained linear regression formula has high reliability and accuracy. Therefore, the determination of surface water quality parameters by the remote sensing method is feasible. From the obtained linear regression equation, a comparison between the results of real measurements and simulations for the remaining 13 samples was performed. The results obtained are real measurements and simulations for high similarity with the RMSE index, bias index, and percentage error. Thus, the simulation results are similar to actual measured data, and this result can be used in assessing the existing surface water quality of Ca Mau city.

Surface water quality parameters were calculated and classified according to QCVN08-MT:2015/BTNMT. The results show that except for $\mathrm{pH}$ values obtained at level $\mathrm{A}$
(A1 and A2), in which water is used for domestic purposes, the remaining parameters are distributed in the levels from B1 to above B2 level as water used for irrigation and water transportation. When considering the VN-WQI index, the two levels 10-25 and 25-50 accounted for a large percentage of the distribution in the surface water area of the whole region and concentrated in the aquaculture, industrial, and residential areas. Meanwhile, the level 50-75 (water used for irrigation purposes) only accounts for a low rate, and the other two are 75-90 and 90-100 (water used for domestic purposes) did not present in surface water areas of the city. Thus, this result indicates that the city's surface water is heavily polluted and can be only used for water transportation.

In conclusion, the method of evaluating surface water quality by satellite image is feasible, and the obtained results are highly accurate and are a reliable reference for other methods such as water quality assessment by a mathematical model. However, this method still has some limitations, such as depending on the quantity and accuracy of the actual measured data, the reflected spectral values are susceptible to atmospheric and cloud errors, limited by image resolution.

\section{ACKNOWLEDGEMENTS}

This research is funded by the Vietnam Ministry of Science and Technology under grant number KC.08.30. We address our sincere gratitude to the SIWRR for supporting the research and the ESA for providing the Sentinel-2 image data source.

\section{REFERENCES}

Abdullah, H.S.E. 2010. Water Quality Assessment for Donkan Lake Using LST8 OLI Satellite Images (Thesis). BSc. Irrigation Engineering, University of Sulaimani, Faculty of Engineering, Irrigation Engineering Department.

Alparslan, E., Aydöner, C., Tufekci, V. and Tüfekci, H. 2007. Water quality assessment at Ömerli Dam using remote sensing techniques. Environ. Monit. Assess., 135(1-3): 391-398.

Chang, N.B., Vannah, B.W., Yang, Y.J. and Elovitz, M. 2014 Integrated data fusion and mining techniques for monitoring total organic carbon concentrations in a lake. International Journal of Remote Sensing 2014, 35: 1064-1093.

Dinh T.T.H. 2018. Study on building a technological process to monitor surface water in the Hanoi area from VNREDSAT-1 data (Vietnamese). Thesis (Master), Hanoi University of Mining and Geology, Faculty of Geosynthetic-Map Engineering, Hanoi.

El-Zeny, A. and El-Kafrawy, S.B. 2016. Assessment of water pollution induced by human activities in Burullus Lake using Landsat 8 operational land imager and GIS. Egypt. J. Remote. Sens. Space Sci., 20: 49-56.

Engman, E.T. and Gurney, R.J. 1991. Remote Sensing in Hydrology, Chapman and Hall Ltd, London.

ESA. 2019. Algorithm Theoretical Basis Document Sentinel 2Global Mosaics. S2GM-SC2-ATBD-BC-V1.3.1.2019. [online]: https://usermanual.readthedocs.io/en/stable/_downloads/fe714f8693d5a208b3684847d762192f/S2GM-SC2-ATBD-BC-v1.3.2.pdf [Accessed 3 October 2020]. 
ESA. 2020. User Guides - Sentinel-2 MSI - Level-2A Product - Sentinel Online. [online] Earth.esa.int. Available at: $<$ https://earth.esa.int/web/ sentinel/user-guides/sentinel-2-msi/product-types/level-2a> [Accessed 3 October 2020].

ESRI. 2020a. How ISO Cluster Works. [online]: https://desktop.arcgis. com/en/arcmap/10.3/tools/spatial-analyst-toolbox/how-iso-clusterworks.htm\#GUID-7B5D7C52-3F6C-4744-BA77-8C4D1C0A27F0 [Accessed 3 October 2020]

ESRI. 2020b. Iso Cluster Unsupervised Classification. [online]: https:// desktop.arcgis.com/en/arcmap/10.3/tools/spatial-analyst-toolbox/ iso-cluster-unsupervised-classification.htm [Accessed 3 October 2020]

Fiorani, L., Fantoni, R., Lazzara, L., Nardello, I., Okladnikov, I. and Palucci, A. 2006. Lidar calibration of satellite sensed cdom in the Southern Ocean. EARSeL eProc., 5: 89-99.

Gholizadeh, M. H. and Melesse, A. M. 2017. Study on spatiotemporal variability of water quality parameters in Florida bay using remote sensing. J. Rem. Sens. GIS, 06(03): 14-39

Gholizadeh, M., Melesse, A. and Reddi, L. 2016. A comprehensive review on water quality parameters estimation using remote sensing techniques. Sensors, 16(8): 1298.

Huynh, H. 2018. Four "Black Spots" Of Environmental Pollution In Ca Mau. Vietnamese. [online] Dan Tri International News. Available at: https://dantri.com.vn/moi-truong/bon-diem-den-o-nhiem-moi-truongo-ca-mau-20180415144101599.htm [Accessed 23 September 2020].

Imen, S., Chang, N.B. and Yang, Y.J. 2014. Monitoring spatiotemporal total organic carbon concentrations in Lake Mead with integrated data fusion and mining (IDFM) technique. 2014 IEEE International Conference on Systems, Man, and Cybernetics (SMC), San Diego, CA, USA, 5-8 October 2014, pp. 1-9.

Kapalanga, M. 2015. Assessment and Development of Remote
Sensing-Based Algorithms for Water Quality Monitoring in Olushandja Dam, North-Central Namibia (Thesis). Master of Science, University of Zimbabwe, Department of Civil Engineering.

Karaoui, I., Abdelkrim, A., Abdelghani, B., Mohammed, H., Sabri El, M., Kamal Ait, O. and Driss, E. 2019. Evaluating the potential of Sentinel-2 satellite images for water quality characterization of artificial reservoirs: The Bin El Ouidane Reservoir case study (Morocco). Meteorol. Hydrol. Water Manag., 7(1): 31-39.

Lim, J. and Choi, M. 2015. Assessment of water quality based on Landsat 8 operational land imager associated with human activities in Korea. Environ. Monit. Assess., 187(6): 313-339.

Ritchie, J. C., Zimba, P. V. and Everitt, J. H. 2003. Remote sensing techniques to assess water quality. Photogramm. Eng. Remote Sens., 69(6): 695-704.

Seyhan, E. and Dekker, A. 1986. Application of remote sensing techniques for water quality monitoring. Hydrobiol. Bull., 20: 41-50.

Vietnam Environment Administration. 2019. Decision 1460/QD-TCMT: On the Issuing of Technical Guide to Calculation and Disclosure Viet Nam Water Quality Indicator (VN_WQI). Ha Noi: Vietnam Environment Administration, pp.1-6.

Vo, T. P. L., Vo, Q. T. and Le, V.H. 2019. Application of Landsat images to estimate suspended sediment concentration in the Hau and Tien rivers (Vietnamese), Can Tho University. J. Sci., 55(2): 134-144.

Waxter, M.T. 2014. Analysis of Landsat Satellite Data to Monitor Water Quality Parameters in Tenmile Lake, Oregon (Thesis). Master of Science, Portland State University, Civil and Environmental Engineering.

Zhu, W., Yu, Q., Tian, Y.Q., Chen, R.F. and Gardner, G.B. Estimation of chromophore dissolved organic matter in the Mississippi and Atchafalaya river plume regions using above surface hyperspectral remote sensing. J. Geophys. Res. - Oceans, 2011: 116. 